\title{
Paget's disease of the jaws: Histopathological features of a series of 31 cases
}

\author{
Nathalie Amaya, María E. Itoiz, María L. Paparella \\ Universidad de Buenos Aires, Facultad de Odontología, Cátedra Anatomía Patología, Laboratorio Patología Quirúrgica
}

\begin{abstract}
The aim of the present study was to analyze the histopathological features of Paget's disease of the jaws observed in a series comprising 31 cases. The study comprised all cases of Paget's disease of the jaws filed in the archives of the Surgical Pathology Laboratory of the Oral Pathology Department, School of Dentistry, University of Buenos Aires, between 1960 and 2018. Their microscopic features were evaluated, and available clinical data and radiographic studies were analyzed. Paget's disease of the jaws accounted for $0.05 \%$ of retrieved oral-maxillofacial pathologies. Microscopically, all cases showed lamellar bone trabeculae with the characteristic mosaic pattern. Twenty cases (64\%) showed osteoblastic-osteoclastic activity, and all showed areas of necrosis. Cemento-osseous trabeculae were observed in 15 cases (48\%), and cementicles were observed in 13 (42\%).
\end{abstract}

Osteomyelitis was seen in 11 cases (35\%), all of which showed cemento-osseous trabeculae with a mosaic structure, sclerosis and necrosis, and chronic inflammation with abscess formation. Mean age was 61 years (44-85 years); 19 cases were women. Localization was the maxilla in 13 cases (42\%), and the disease involved other skeletal bones in five cases. To our knowledge, this is the largest series of Paget's disease of the jaws reported to date. Paget's disease is infrequent in the jaws and has distinct histopathological features that not only differ from those observed at other skeletal sites but also require differential diagnosis from other pathologies affecting the jaws exclusively.

Received: September 2021; Accepted: November 2021.

Keywords: Paget's disease - diseases of bone - diseases of jaws.

\section{Enfermedad de Paget en los maxilares. Características histopatológicas de una serie de 31 casos}

\begin{abstract}
RESUMEN
El objetivo del presente trabajo fue analizar las características histopatológicas de la enfermedad de Paget en los maxilares en una serie de 31 casos. El estudio comprendió todos los casos de enfermedad de Paget de los maxilares provenientes del Laboratorio de Patología Quirúrgica de la Cátedra de Anatomía Patológica de la Facultad de Odontología de la Universidad de Buenos Aires, entre 1960 y 2018. Se evaluaron las características microscópicas y se analizaron los datos clínicos y estudios radiográficos disponibles. La enfermedad de Paget en los maxilares representó el 0,05\% de las patologías buco-maxilofaciales. Microscópicamente, todos los casos mostraron trabéculas óseas laminares con el característico patrón en mosaico. Veinte casos (64\%) mostraron actividad osteoblástica-clástica y todos los casos mostraron necrosis focal. En 15 casos (48\%) las trabéculas presentaron aspecto cemento-óseo y en 13 casos (42\%) se observaron cementículos.
\end{abstract}

Once casos (35\%) presentaron cuadros osteomielíticos y todos ellos mostraron trabéculas cemento-óseas con estructura en mosaico, esclerosis y necrosis, e infiltrado inflamatorio crónico con formación de abscesos. La media de edad fue 61 años (4485 años), y 19 fueron mujeres. Trece casos (42\%) se localizaron en maxilar superior y 5 casos presentaron compromiso de otros huesos. A nuestro entender, esta es la serie más grande de enfermedad de Paget en los maxilares reportada hasta la fecha. La enfermedad de Paget es poco frecuente en los maxilares y presenta características histopatológicas que además de ser diferentes a las observadas en otros sitios del esqueleto plantean el diagnóstico diferencial con otras entidades que se presentan exclusivamente en los maxilares.

Palabras clave: enfermedad de Paget - lesiones óseas - lesiones de los maxilares. 


\section{INTRODUCTION}

Paget's disease of bone (PDB) is a chronic disease characterized by abnormal bone turnover affecting one or more bones of the skeleton ${ }^{1-3}$. It was first described in 1877 by Sir James Paget who named it osteoitis deformans ${ }^{4}$. It occurs in patients over the age of 55 years and is more prevalent in men (M:F ratio: $2: 1)^{5,6}$.

PDB has an unusual geographic distribution, with an increased incidence in the United Kingdom, Germany, France, New Zealand, and Australia ${ }^{6,7}$, and being less common in China, Japan, India, Southeast Asia and America ${ }^{8-13}$. The incidence and severity of Paget's disease has decreased over the last 35 years ${ }^{14-17}$.

Although the etiology of the disease remains unclear, association with different underlying conditions has been suggested. The familial occurrence of PDB has prompted genetic studies, which have reported a mutation in the gene SQSTM1 ${ }^{18,19}$. In turn, the decrease in the incidence of the disease has brought about the search for environmental factors ${ }^{14,18-21}$. A possible viral etiology has also been suggested based on evidence of measles virus nucleocapsid protein in pagetic osteoclasts ${ }^{22,23}$.

Paget's disease is asymptomatic in the early stages of the disease, in which osteoclastic activity predominates, subsequently causing an increase in osteoblastic activity that leads to sclerosis and bone deformity. Signs and symptoms vary with progression of the disease according to the affected skeletal site. The most common presenting features are pain, deafness, bone deformities, osteoarthritis, pathological fracture, and, though very rarely, malignant transformation ${ }^{6,24-28}$.

When the disease involves the jaws, it occurs predominantly in the maxilla, which undergoes progressive enlargement causing displacement of the teeth and malocclusion ${ }^{29,30}$. With time, the disproportion in the size between the maxilla and the mandible gives rise to the inverted triangle type of facial contour ${ }^{3,30}$.

Regardless of the affected skeletal site, the microscopic features of PDB vary throughout the course of the disease. In the early phase, active bone resorption predominates, showing abnormally large osteoclasts containing multiple nuclei. The haversian canals enlarge and coalesce, and the bone marrow shows highly vascularized loose fibrous tissue $^{6,30}$. The intermediate stages of the disease are characterized by dysregulated bone remodeling in which active osteoblastic activity coexists with osteoclastic activity, leading to apposition of new bone on the surfaces of the previously resorbed trabeculae. Uncoordinated bone resorption and apposition results an anarchic trabecular structure and altered mechanical properties. Finally, the last phase of Paget's disease is characterized by sclerotic lamellar bone trabeculae with multiple compartments separated by irregularly arranged incremental and reversal lines, resulting in the characteristic microscopic appearance of PDB with the typical mosaic or jigsaw puzzle pattern ${ }^{2,6,31}$.

In addition to the histologic characteristics described above, Paget's disease of the jaws shows specific features. In the osteolytic phase, varying degrees of tooth mobility and ultimately tooth loss may occur ${ }^{3,29-31}$. In the intermediate phase, hypercementosis with ankylosis of teeth to the adjacent bone and the presence of spherical structures similar to psammoma bodies can be observed. In the later stages of the disease, these spherical structures fuse and a fibrillar structure can be seen on their surface ${ }^{29-31}$.

Radiographic features vary widely with the stage of the disease and osteoclastic/osteoblastic activity. A radiodense image with a cotton wool appearance is typically seen in the intermediate and late phases $^{29,31,32-36}$.

Diagnosis is mainly based on radiographic studies, bone scintigraphy, and evaluation of serum bone turnover markers. A biopsy is nevertheless necessary not only to confirm diagnosis, especially in controversial cases where differential diagnosis from other diseases must be established, but also for a better understanding of the biological behavior of the disease.

The main differential diagnoses of Paget's disease of the jaws include cemento-osseous dysplasia ${ }^{31,32}$, chronic sclerosing osteomyelitis ${ }^{31}$ and medicationrelated osteonecrosis of the jaws ${ }^{36}$. In view of the increasing incidence of the latter, a complex and emerging pathological condition, it is highly relevant to gain further knowledge about pathological entities with similar morphologic characteristics, as is the case of Paget's disease of the jaws ${ }^{37,38}$.

The aim of the present study was to perform a detailed analysis of the histopathological features of Paget's disease of the jaws observed in a series comprising 31 cases. To our knowledge, this is the 
largest series of Paget's disease of the jaws reported to date.

\section{MATERIALS AND METHODS}

The study projet was approved by the Ethics Committee of the School of Dentistry of the University of BuenosAires (\# 20020170200308BA). The study comprised all cases of Paget's disease of the jaws $(n=31)$ filed in the archives of the Surgical Pathology Laboratory of the Oral Pathology Department, School of Dentistry, University of Buenos Aires, between 1960 and 2018. The microscopic features of the hematoxylin-eosinstained histological sections were analyzed and recorded, and the clinical and radiographic data available on the filed records were examined.

\section{RESULTS}

The 31 retrieved cases of Paget's disease of the jaws accounted for $0.05 \%$ of all oral-maxillofacial pathologies diagnosed at our laboratory in the studied period (58 years).
Mean age was 61 years, age range 44 to 85 years, and frequency peaked in the sixth decade of life. Nineteen cases (61\%) were women. The most frequently affected site was the maxilla (13 cases). No information regarding mandibular or maxillary location was available in seven cases, and the disease involved other skeletal bones (polyostotic form) in five cases.

Microscopically, all cases showed the typical trabecular structure: lamellar trabeculae with a mosaic pattern containing multiple compartments. The observed compartments were mostly demarcated by resorption lines (Fig. 1A). Trabeculae were markedly thicker in 24 cases $(77 \%)$. Twenty cases $(64 \%)$ showed osteoblastic and osteoclastic activity (Fig. 1B) and 11 cases (35\%) showed no cellular activity (Fig.1C). All cases exhibited areas of necrosis evidenced by the absence of osteocytes inside lacunae. The medullary spaces were occupied by fibrous tissue, which was mostly loose and well vascularized. The observed microscopic features were consistent with Paget's disease of bone. The
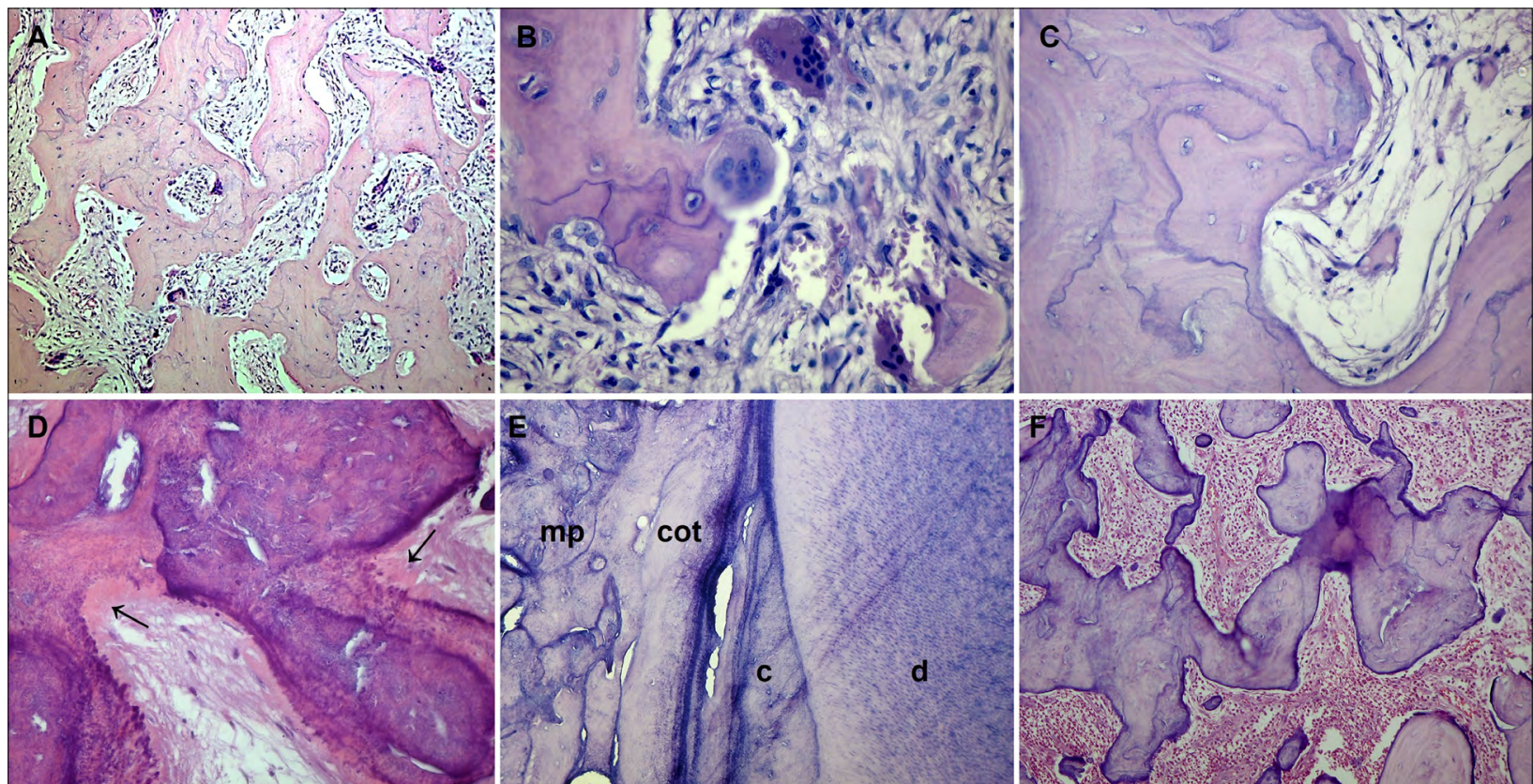

Fig. 1: Photomicrographs of Paget's disease of the jaws.

A. Lamellar bone trabeculae showing a mosaic pattern, and fibrous bone marrow. H-E Orig. Mag. X100.

B. Osteoblasts and osteoclasts on the surface of the bone trabecula. H-E Orig. Mag. X400.

C. Absence of cells on the surface of the trabecula. H-E Orig. Mag. X400.

D. Cemento-osseous trabeculae with a fibrillar surface (个). H-E Orig. Mag. X400.

E. Tooth root exhibiting hypercementosis and ankylosis. $d$ : dentine ; c: cement; cot: cemento-osseous trabecula; mp: Mosaic pattern. H-E Orig. Mag. X400

F. Necrotic cemento-osseous trabeculae with multiple compartments and medullary spaces occupied by an inflammatory process. H-E Orig. Mag. X100. 
occurrence of cemento-osseous trabeculae in 15 cases $(48 \%)$ was a remarkable finding. The latter trabeculae were mineralized structures arranged in the typical mosaic pattern but had rounded and scalloped surfaces with less cellularity, resembling cementum. Some sectors of the surface exhibited fibrillar structures as those described by Cooke ${ }^{30}$ (Fig. 1D). Cementicles were observed in 13 cases $(42 \%)$. The involved tooth was submitted for histopathological examination in two cases, and both submitted teeth were found to exhibit cementum apposition resulting in hypercementosis and ankylosis with the typical mosaic pattern (Fig. $1 \mathrm{E})$. Osteomyelitis was observed in 11 cases $(35 \%)$, which were clinically and radiographically diagnosed as osteomyelitis associated with Paget's disease of the jaws. All the cases exhibited thick cementoosseous trabeculae with multiple compartments and necrosis. An acute/chronic inflammatory process and microbial colonies were observed in the bone marrow (Fig.1F).

\section{DISCUSSION}

Few case series of Paget's disease of the jaws have been reported in the literature to date; all comprised a small number of cases and were mostly published in the $80^{\prime}$ s, $^{293-35}$. In 2012, Werner de Castro et al. published a series of 134 cases of Paget's disease of bone, which included only five cases located in the jaws ${ }^{36}$.

There is no available information on the incidence and frequency of Paget's disease of the jaws in Argentina. We herein report 31 cases of Paget's disease of the jaws diagnosed at a single referral center within a period of 58 years, and that accounted for $0.05 \%$ of all oral maxillofacial pathologies filed in the laboratory archives. To our knowledge, this is the largest series of cases of this disease reported to date. Sixty-five of the cases in this series were diagnosed before 1980, confirming the decreasing trend in the incidence of the disease worldwide.

In addition to the typical histopathological characteristics of Paget's disease involving other bones of the skeleton, Paget's disease of the jaws shows formation of cemento-osseous trabeculae and cementicles. The latter histopathological feature could be misleading, and diagnosis can be confused with other dysplastic and neoplastic diseases affecting the jaws, such as cementoosseous dysplasia, cementoblastoma, and ossifying cemento-fibroma. These pathologies affect the jaws exclusively; the former is dysplastic, the latter two are tumor lesions of odontogenic origin, and all threes show formation of cemento-osseous trabeculae with a paget-like pattern.

Paget's disease of bone is infrequent in the jaws. Most studies on this pathological entity reported the clinical and radiographic features, but few analyzed the specific histopathology and possible etiopathogenesis of the disease in this location ${ }^{29-31}$.

Rushton (1938) was the first author to report hypercementosis of the teeth in Paget's disease of the jaws ${ }^{29}$. Lucas (1955) pointed out that the observed hypercementosis could be differentiated from hypercementosis related with other causes by the absence of periodontal ligament and lamina dura; the author also found that hypercementosis becomes evident in the later stages of the disease ${ }^{30}$. Cook (1956) analyzed five teeth with root hypercementosis from patients with Paget's disease of the jaws, and observed marked cellularity in the newly-formed cementum, which in turn showed signs of remodeling in a mosaic pattern similar to that described in bone tissue. The author also observed nodules of bone fused together by woven bone that had a fibrillar structure on its surface, at right angles to the central nodules ${ }^{29}$.

In our case series, 15 cases (48\%) exhibited cemento-osseous trabeculae with marked signs of remodeling in a mosaic pattern, and in line with the aforementioned authors, showed a fibrillar pattern on the surface of the trabeculae. Thirteen cases (42\%) showed cementicles, and the two cases submitted with the involved teeth for histopathological evaluation exhibited hypercementosis with tooth ankylosis and the typical mosaic pattern.

It is known that formation of Paget-like trabeculae increases risk of infection. Eleven cases of Paget's disease of the jaws in our series (36\%) showed osteomyelitis, and their microscopic features were similar to those reported in bisphosphonaterelated osteonecrosis of the jaws. Our research group found the Paget-like trabecular structure containing multiple compartments to be a distinctive microscopic feature of bisphosphonate-related osteonecrosis $^{37-38}$. Based on this observation, we have posited the existence of an etiopathogenic mechanism that might also explain the necrosis and inflammation seen in Paget's disease of the jaws. Bisphosphonates induce new bone formation and 
are therefore used in oncological treatment to limit metastasis-related bone destruction and to treat different bone metabolism alterations. Similarly, a mechanism that remains unknown to date would cause the chaotic bone architecture found in Paget's disease, favoring necrosis and the subsequent inflammation and invasion of oral microorganisms into the bone.

Of note, we observed a subtle difference between the mosaic pattern of trabeculae in Paget's disease of the jaws and the Paget-like structure of trabeculae in bisphosphonate-related osteonecrosis of the jaws: in the latter condition the cement lines are regular and linear, following the laminar arrangement of trabeculae, whereas in Paget's disease of the jaws, they show a scalloped appearance indicating reabsorption. Although diagnosis of both pathological entities is defined based on clinical and biochemical data, in-depth analysis of their microscopic features could contribute to differential diagnosis and provide a better understanding of

\section{DECLARATION OF CONFLICTING INTERESTS}

The authors declare no potential conflicts of interest regarding the research, authorship, and/or publication of this article

\section{FUNDING}

This study was supported by a grant from the Buenos Aires University, UBACYT project 20020190200350BA.

\section{REFERENCES}

1. Ralston SH, Layfield R. Pathogenesis of Paget disease of bone. Calcif Tissue Int 2012;91:97-113.

2. Shaker JL. Paget's disease of bone: a review of epidemiology, pathophysiology, and management. Ther Adv Musculoskel Dis 2009;1:107-125.

3. Smith BJ, Evenson JW. Paget's disease of bone with particular reference to dentistry. J Oral Pathol 1981;10:233247.

4. Paget J. On a form of chronic inflammation of bones (osteitis deformans). Med Chir Trans 1877;60:37-64.

5. Roodman GD, Windle JJ. Paget disease of bone. J Clin Invest 2005;115:200-208. .

6. Santini Araujo E: Paget's disease of bone and sarcoma complicating Paget's disease. In: Santini Araujo E, Kalil RK, Bertoni F, Park YK: Tumors and tumor like lesions of bone. London, United Kingdom. Springer, 2015:875-894.

7. Van Staa TP, Selby P, Leufkens HGM, Lyles K et al. Incidence and natural history of Paget's disease of bone in England and Wales. J Bone Miner Res 2002;17:465-471.

8. Wat WZ, Cheung WS, Lau TW. A case series of Paget's disease of bone in Chinese. Hong Kong Med J 2013;19: 242-248. the biological behavior and pathogenesis of these complex diseases.

All the cases of Paget's disease of the jaws presenting osteomyelitis showed cemento-osseous trabeculae, which were thicker and contained multiple compartments. Formation of cemento-osseous trabeculae is likely reactive to inflammation, and these trabeculae probably have little or no repair capacity.

It must be pointed out that when bone pathologies are in the jaws, they usually have distinct characteristics that are different from those observed when they are located in other bones of the skeleton. This is especially evident, for example, in osteosarcoma of the jaws and medication-related osteonecrosis of the jaws, as well as in Paget's disease of the jaws. These differences could be attributed to the greater remodeling activity of the jaws due to stimuli of the masticatory forces and to the persistence of and/or coexistence with tissues that have the potential to form cementum-like and dentin-like structures.

\section{CORRESPONDENCE}

Dra. María L. Paparella.

Cátedra de Anatomía Patológica,

Facultad de Odontología, UBA.

M.T. Alvear 2142. $2^{\circ} \mathrm{A}$.

(C1122AAH) Ciudad Autónoma de Buenos Aires, Argentina. maria.paparella@odontologia.uba.ar

9. Bhadada S, Bhansali A, Unnikrishnan AG, Khadgawat R et al. Does Paget's disease exist in India? a series of 21 patients. J Assoc Physicians India 2006;54:530-534.

10. Sirikulchayanonta V, Jaovisidha S, Subhadrabandhu T, Rajatanavin R. Asymptomatic Paget's bone disease in ethnic Thais: a series of four case reports and a review of the literature. J Bone Miner Metab 2012;30:485-492.

11. Rojas - Villarraga A, Patarroyo PA, Contreras A, Restrepo JF et al. Paget disease of bone in Colombia and Latin America. Clin Rheumatol 2006;12:57-60.

12. Acotto CG, Mautalen CA. European origin of patients with Paget's disease of bone in the Buenos Aires area. Eur J epidemiol 2001;17:409-411..

13. González G, Brusco F, Arteaga L, Rodríguez J et al. Paget disease of bone in Chile: report of 15 cases. Rev Med Chil 2003;131:491-497.

14. Cooper C, Schafheutle K, Dennison E, Kellingray S et al. The epidemiology of Paget's disease in Britain: is the prevalence decreasing? J Bone Miner Res 1999;14:192-197.

15. Cundy HR, Gamble G, Wattie D, Rutland M et al. Paget's disease of bone in New Zealand: continued decline in disease severity. Calcif Tissue Int 2004;75:358-364. 
16. Cundy T. Is the prevalence of Paget's disease of bone decreasing? J Bone Miner Res 2006;21:9-13.

17. Doyle T, Gunn J, Anderson G, Gill M et al. Paget's disease in New Zealand: evidence for declining prevalence. Bone 2002;31:616-619.

18. Hocking LJ, Lucas GJA, Daroszewska A, Mangion J et al. Domain-specific mutations in sequestosome 1 (SQSTM1) cause familial and sporadic Paget's disease. Hum Mol Genet 2002;11:2735-2739. .

19. Hiruma Y, Kurihara N, Subler MA, Zhou H et al. A SQSTM1/ p62 mutation linked to Paget's disease increases the osteoclastogenic potential of the bone microenvironment. Hum Mol Genet 2008; 17:3708-3719.

20. Helfrich MH. Osteoclast diseases and dental abnormalities. Arch Oral Biol 2005;50:115-122.

21. Hughes AE, Ralston SH, Marken J, Bell C et al. Mutations in TNFRSF11A, affecting the signal peptide of RANK, cause familial expansile osteolysis. Nat Genet 2000;24:4548.

22. Basle MF, Fournier JG, Rozenblatt S, Rebel A et al. Measles virus RNA Detected in Paget's disease bone tissue by in situ hybridization. J Gen Virol 1986;67:907-913.

23. Birch MA, Taylor W, Fraser WD, Ralston SH et al. Absence of paramyxovirus RNA in cultures of pagetic bone cells and in pagetic bone. J Bone Miner Res 1994;9:11-16.

24. Tan A, Ralston SH. Clinical presentation of Paget's disease: evaluation of a contemporary cohort and systematic review. Calcif Tissue Int 2014;95:385-392.

25. Cushing FR, Bone HG. Radiographic diagnosis and laboratory evaluation of Paget's disease of bone. Clinic Rev Bone Miner Metab 2002;1:115-134.

26. Kaplan FS, Haddad JG, Singer FR. Paget's disease: complications and controversies. Calcif Tissue Int 1994;55:75-78.

27. Schajowicz F, Santini Araujo E, Berenstein M. Sarcoma complicating Paget's disease of bone A clinicopathological study of 62 cases. J Bone Joint Surg Br 1983;65:299-307.
28. Hansen MF, Seton M, Merchant A. Osteosarcoma in Paget's disease of bone. J Bone Miner Res 2006;21:58-63.

29. Cooke BE. Paget's disease of the jaws: fifteen cases. Ann R Coll Surg Engl 1956;19:223-240.

30. Lucas RB. The jaws and teeth in Paget's disease of bone. J Clin Pathol 1955;8:195-200.

31. Eversole R, Su L and ElMofty S. Benign fibro osseous lesions of the craniofacial complex. A review. Head Neck Pathol 2008;2:177-202.

32. Carrillo R, Morales A, Rodriguez-Peralto JL, Lizama J et al. Benign fibro-osseous lesions in Paget's disease of the jaws. Oral Surg Oral Med Oral Pathol 1991;71:588-592.

33. Stafne EC, Austin LT. Study of dental roentgenograms in cases of Paget's disease (osteitis deformans), osteitis fibrosa cystic and osteoma. J Am Dent Assoc 1938;25:1202-1214.

34. Tillman HH. Paget's disease of bone. A clinical, radiographic and histopathologic study of twenty four cases involving the jaws. Oral Surg Oral Med Oral Pathol 1962;15:12251234.

35. Gardner AF, Drescher JT, Goodreau GJ. Study of 24 cases of Paget's disease involving the maxilla and mandible with reference to dentistry J Cal Dent Assoc 1963; 39: 105-116. DOI: 10.1016/0030-4220(65)90293-8.

36. Werner de Castro GR, Heiden GI, Zimmermann AF, Morato EF et al. Paget's disease of bone: analysis of 134 cases from an island in Southern Brazil: another cluster of Paget's disease of bone in South America. Rheumatol Int 2012;32:627-631.

37. Paparella ML, Brandizzi D, Santini-Araujo E, Cabrini RL. Histopathological features of osteonecrosis of the jaw associated with bisphosphonates. Histopathology 2012;60:514-516.

38. Paparella ML, Brandizzi D, Santini-Araujo E, Cabrini RL. Osteonecrosis of the jaw associated with bisphosphonates. A histopathological study of 24 cases. JSM Dent 2014;2:1037. https:/www.jscimedcentral.com/Dentistry/ dentistry-spid-oral-cancer-1037.pdf 